\title{
Effects of arbuscular mycorrhizal inoculation and phosphorus fertilization on the growth of escarole (Cichorium endivia L.) in an arsenic polluted soil
}

\author{
M. Pigna ${ }^{1 *}$, A.G. Caporale ${ }^{1}$, P. Cartes $^{2}$, V. Cozzolino ${ }^{1}$, M. Mora ${ }^{2}$, A. Sommella ${ }^{1}$, A. Violante ${ }^{1}$ \\ ${ }^{1}$ Dipartimento di Agraria, Università degli Studi di Napoli, Napoli, Italy. ${ }^{2}$ Departamento de Ciencias Químicas y Recursos \\ Naturales, and Scientific and Technological Bioresource Nucleus (BIOREN-UFRO), Universidad de La Frontera, Temuco, \\ Chile."Corresponding author: massimo.pigna@unina.it
}

\begin{abstract}
We have studied the effects of P fertilization and AMF inoculation on the growth of escarole (Chicorium endivia L.) plants ,grown in both As-non-contaminated (Padula) and As-contaminated (La Botte) soils and As and P uptake by these plants.

Our study demonstrated that the combined use of AMF inoculation and P fertilization can significantly increase the production of biomass of escarole plants, even if grown in highly As-contaminated soils. In addition, this dual agricultural practice has also allowed to reduce the translocation of the harmful element from roots to leaves minimizing, hence, the accumulation of highly toxic levels of As in the edible part of the escarole.
\end{abstract}

Therefore, the combined use of AMF inoculation and P fertilization may alleviate the As toxicity to sensitive plants as Cichorium endivia, by promoting their growth, limiting As assimilation and improving P nutrition.

Keywords: Arsenic, polluted soil, escarole, arbuscular mycorrhizal fungi, phosphorus

\section{Introduction}

Arsenic (As) is one of the most hazardous metalloid present in almost all environments. Exposure to high As concentrations can cause several diseases including arsenicosis, cancers, hyperkeratosis, restrictive lung diseases, and ischemic heart diseases (Frankenberger, 2002).

Arsenic is stable in several oxidation states (-III, $0,+$ III, $+\mathrm{V})$, but $\mathrm{As}(\mathrm{III})$ and $\mathrm{As}(\mathrm{V})$ states are the most common in natural systems. The toxicity of As depends mainly on its chemical form and is dictated in part by the valence state. Trivalent As has a high affinity for thiol groups, as it readily forms kinetically stable bonds to sulfur. Thus reaction with As(III) induces enzyme inactivation, as thiol groups are important to the functioning of many enzymes (Ahuja, 2008). Pentavalent As has a poor affinity toward thiol groups, resulting in its more rapid excretion from the body. High concentrations of As in groundwater have been found in Argentina, Chile, Mexico, China, Hungary, West Bengal (India), Bangladesh and Vietnam (Smith et al. 1998; Mandal and Suzuky, 2002; Pigna et al., 2009). 
Up to around 30-35 million people in Bangladesh are estimated to be exposed to As in drinking water at concentration above $50 \mu \mathrm{g} \mathrm{L}^{-1}$ and 6 million in West Bengal (Chakrabarti et al. 2002; Frankenberger, 2002; Mandal and Suzuky 2002; Pigna et al., 2009).

The observation that As in the world's population is not consistent with the level of water intake has raised questions regarding possible pathways of As transfer from groundwater to the human body (Stone, 2008). Even if an As-safe drinking water supply could be ensured, the same groundwater will continue to be used for irrigation purpose, leaving a risk of soil accumulation of this toxic element and eventual exposure to the food chain through plant uptake and animal consumption.

Arsenic uptake by plants can be also influenced by soil microorganisms closely associated with plant roots to form a rhizosphere community, such as the arbuscular mycorrhizal fungi (AMF) (Cozzolino et al., 2010; Violante et al., 2012). Arbuscular mycorrhizal fungi are symbiotic microorganisms associated with the plant roots. Strong evidences suggest that external hyphae of AMF take up immobile nutrients such as $\mathrm{P}$, $\mathrm{Zn}$ and $\mathrm{Cu}$ from soil and translocate them rapidly to host plant (Smith and Read, 2008).

The interaction between AMF colonization and accumulation of toxic elements is an area of considerable interest for both the production of safe food and the bioremediation programs (Smith and Read, 2008., and Smith et al., 2010; Cozzolino et al., 2010). Arbuscular mycorrhizal fungi significantly influence As metabolism in plants (Meharg and Hartley-Whitaker., 2002 and Smith et al., 2010). Thus, they can exert protective effects on vascular plants under As contamination by decreasing As accumulation, by transforming inorganic As into less toxic organic forms or by diluting As concentration by enhancing plant biomass (Gonzalez-Chavez et al., 2002, Liu et al., 2005a, Chen et al., 2007, Ultra et al., 2007, Wu, 2008., and Xu et al., 2008).
The aim of the inoculation is to enhance the soil's inoculum potential to improve plant productivity. It is useful to investigate the possible combination of agricultural practices, such as fertilizers application with mycorrhizal inoculation technology to make possible successful harvesting of food crops, safe for human consumption and for effective restoration of contaminated sites (Cozzolino et al., 2010).

Therefore, in this study carried out in both Asnon-contaminated (Padula) and As-contaminated (La Botte) soils, we evaluated the effects of $\mathrm{P}$ fertilization and AMF inoculation on the growth of escarole (Chicorium endivia L.) plants and their As and $\mathrm{P}$ uptake. Escarole was selected as a test plant in this study, because this crop is cultivated in the contaminated area and suffers from As toxicity.

\section{Materials and Methods}

\subsection{Soil properties, physico-chemical and chemical analyses}

The soils used in the experiments were collected from the subsurface layer $(5-25 \mathrm{~cm})$ of an industrial-mining area in the plain of Scarlino (Grosseto), Tuscany, Italy. Two sampling sites were selected in the area: (1) a site (La Botte) near an abandoned smelting factory, with high As concentration and (2) a site (Padula) about $2 \mathrm{~km}$ from the first site, with low-As concentration (Table 1).

After air-drying, the soil samples for cultivation of escarole and chemical analyses were passed through 5- and 2-mm mesh sieves, respectively.

Soil fractions were separated by pipette and sieving following pre-treatment with $\mathrm{H}_{2} \mathrm{O}_{2}$ to oxidize organic matter. Soil $\mathrm{pH}$ was measured by potentiometry in distilled water (1:2.5 soil:water ratio).

Organic matter was determined by the modified Walkley-Black procedure (Nelson and Sommers, 1982). 
Table1. Selected physico-chemical and chemical properties of the As-non-contaminated (Padula) and Ascontaminated (La Botte) soils.

\begin{tabular}{|c|c|c|c|c|c|c|c|c|c|c|c|}
\hline \multirow[t]{2}{*}{ Soil } & Sand & Silt & Clay & \multirow[t]{2}{*}{ pH } & \multirow{2}{*}{$\begin{array}{l}\text { O.C. } \\
\mathrm{g} \mathrm{kg}^{-1}\end{array}$} & \multirow{2}{*}{$\begin{array}{l}\text { Total As } \\
\text { mg kg }^{-1}\end{array}$} & \multirow{2}{*}{$\begin{array}{c}\text { Available } P \\
\mathrm{mg} \mathrm{kg}^{-1}\end{array}$} & $\mathbf{A l}_{\mathbf{o}}$ & $\mathbf{A} \mathbf{l}_{\mathbf{d}}$ & $\mathbf{F e}_{\mathrm{o}}$ & $\mathrm{Fe}_{\mathrm{d}}$ \\
\hline & & $\mathrm{g} \mathrm{kg}^{-1}$ & & & & & & \multicolumn{4}{|c|}{$\mathrm{g} \mathrm{kg}^{-1}$} \\
\hline Padula & $310.0 \pm 8.9$ & $341.0 \pm 7.8$ & $349.0 \pm 10.3$ & $8.2 \pm 0.1$ & $10.8 \pm 0.2$ & $10.0 \pm 0.2$ & $7.6 \pm 0.3$ & $1.0 \pm 0.06$ & $1.2 \pm 0.05$ & $2.8 \pm 0.2$ & $9.1 \pm 0.4$ \\
\hline La Botte & $293.0 \pm 6.9$ & $365.0 \pm 10.4$ & $342.0 \pm 9.1$ & $8.1 \pm 0.2$ & $11.5 \pm 0.3$ & $250.0 \pm 2.8$ & $6.8 \pm 0.4$ & $1.1 \pm 0.08$ & $1.4 \pm 0.10$ & $5.1 \pm 0.3$ & $9.3 \pm 0.6$ \\
\hline
\end{tabular}

Amorphous iron and aluminium oxides $\left(\mathrm{Fe}_{\mathrm{o}}\right.$ and $\left.\mathrm{Al}_{\mathrm{o}}\right)$ were determined by ammonium oxalate extraction method (Blakemore et al., 1987). Crystalline iron and aluminium oxides $\left(\mathrm{Fe}_{\mathrm{d}}\right.$ and $\left.\mathrm{Al}_{\mathrm{d}}\right)$ were determined by the oxalate-ascorbic acid extraction method of Shuman (1982). Available P concentration was determined by ICP-AES using $0.5 \mathrm{M} \mathrm{NaHCO}_{3}$ as the extractant (Olsen method). Total As and $\mathrm{P}$ of soil samples were extracted with concentrated $\mathrm{HNO}_{3}$ and $\mathrm{HF}$ at 5:1 ratio. The concentration of total As was determined using hydride generation-inductively plasma-atomic emission spectrometry (HG-ICP-AES) and total P was analyzed by ICP-AES (Table 1).

\subsection{Greenhouse assay}

A greenhouse assay was conducted with escarole (Chicorium endivia cv. Natacha) plants grown in pots filled with $8 \mathrm{~kg}$ of As-non-contaminated (Padula) or As-contaminated (La Botte) soil. The experimental design consisted of factorial combinations of two levels of AMF (M+ and M-) inoculation (provided by a commercial inoculum) and two levels of $\mathrm{P}(\mathrm{P}+$ and $\mathrm{P}-)$ application, with six replications. The commercial arbuscular mycorrhizal inoculum (100 infective propagules of AMF per gram of product, information provided by the supplier) consisted of a mixture of calcined clay containing spores, hyphae and root fragments colonized by Glomus intraradices (AEGIS ${ }^{\circledR}$ produced by Italpollina, Rivoli Veronese, Italy, for the purpose of being used in agricultural systems). A basal fertilizer, consisting of $0.38 \mathrm{~g} \mathrm{pot}^{-1} \mathrm{~N}$ as $\mathrm{NH}_{4} \mathrm{NO}_{3}$ and
$1.45 \mathrm{~g} \mathrm{pot}^{-1} \mathrm{~K}$ as $\mathrm{K}_{2} \mathrm{SO}_{4}$ was supplied as solution. In the $\mathrm{P}(\mathrm{M}+\mathrm{P}+$ and $\mathrm{M}-\mathrm{P}+)$ treatments, $0.25 \mathrm{~g} \mathrm{pot}^{-1} \mathrm{P}$ as $\mathrm{KH}_{2} \mathrm{PO}_{4}$ were supplied. In the $\mathrm{P}$ - treatments $(\mathrm{M}+\mathrm{P}$ - and $\mathrm{M}-\mathrm{P}-), 0.31 \mathrm{~g} \mathrm{pot}^{-1} \mathrm{~K}$ were added to compensate the $\mathrm{K}$ applied in the $+\mathrm{P}$ treatments. Initially, the greenhouse experiment was conducted in a controlled room at $25 \pm 5^{\circ} \mathrm{C}$ with 10 -h sunlight photoperiod. Escarole was seeded in a polystyrene alveolar container, filled with a mixture of As -non-contaminated or -contaminated soil and commercial potting soil $(70 \%$ soil in the final mixture). Four weeks after germination, seedlings were transplanted into the pots (one seedling per pot, 6 pots per treatment). At transplanting the $\mathrm{M}+$ treatments received $2.5 \mathrm{~g}$ of commercial inoculum per pot, applied just beneath the plant in such a way that the contact between the product and the plant was as direct as possible.

The pots were maintained at room temperature and illuminated with natural light, from May to early July 2012. During the growth period, soil moisture was maintained at $75 \%$ field capacity by periodically adding water to compensate water loss.

\subsection{Plants harvest and chemical analyses}

Plants were harvested 2 months after transplanting. Leaves and roots were sampled separately. Leaves were removed by cutting the base of the plant $1 \mathrm{~cm}$ above the soil surface with a sharp knife. All plant tissues (roots and leaves) were washed with deionized water to remove soil residues and dried for two days at 
$70{ }^{\circ} \mathrm{C}$. The dried tissues were weighed, ground using a PM 200 ball mill (Retsch) and digested in a microwave (Milestone, Digestor/Dring Ethos 900). Sub-samples (about $0.5 \mathrm{~g}$ ) were accurately weighed into PTFE vessels and $7 \mathrm{~mL}$ of $\mathrm{HNO}_{3}(65 \%)$ and $2 \mathrm{~mL} \mathrm{H}_{2} \mathrm{O}_{2}$ added.

Solutions obtained were diluted to $50 \mathrm{~mL}$ and analyzed for As using hydride generation-inductively plasma-atomic emission spectrometry (HG-ICPAES). The $\mathrm{P}$ content was determined in the same digested solutions using ICP-AES. All analyses were carried out in triplicate. In each analytical run at least one reagent blank and one sample of internationally certified reference material (Oriental tobacco leaves CTA-OTL-1) were included to assess precision and accuracy of the chemical analysis.

\subsection{Statistical analysis}

Data were analysed by two-way ANOVA with factor AMF inoculation and P fertilization tested for normality using the Shapiro-Wilk test. Comparison between means were made by the Tukey's test at a significance level of $5 \%$.

\section{Results and Discussion}

\subsection{Plant growth}

In Table 2 are reported the data on the production of biomass (leaves and roots) of escarole grown in both As-non-contaminated (Padula) and As-contaminated (La Botte) soils. These data evidence that the presence of As in the soil causes a drastic reduction of plant biomass, regardless $\mathrm{M}$ treatment; hence, escarole results to be a very sensitive plant to As exposure. In particular, the total biomass of mycorrhized and fertilized plants $(\mathrm{M}+\mathrm{P}+)$ grown in La Botte soil was $52.4 \%$ lower than that of the plants grown in Padula soil. Similarly, the nonmycorrhized and fertilized (M- $\mathrm{P}+$ ), the mycorrhized and non-fertilized (M+ P-) and the non-mycorrhized and non-fertilized (M- P-) plants, grown in La Botte soil, produced a lower biomass $(59.3 \%, 70.9 \%$ and $72.8 \%$, respectively) than that of the plants grown in Padula soil (Table 2). Many studies about the influence of As on plant growth have shown that plant species not resistant to As suffer considerable stress upon exposure, with symptoms ranging from the inhibition of root growth to death (Carbonell-Barrachina et al. 1997; Meharg and Macnair 1991; Paliouris and Hutchinson 1991). Arsenic toxicity symptoms started to appear on the escarole plants few days after transplanting in the contaminated soil (as evident from red-brown necrotic spots on the leaves) and in some cases followed by the senescence of the leaves. Nevertheless, none escarole plants died during the study. Comparing the roots/ leaves ratio (Table 2) of escarole plants grown in the As-contaminated soil (mean value $=0.14$ ) versus that of As-contaminated soil (mean value $=0.25$ ), we can also highlight as the presence of a high concentration of As in soil determined a strong abiotic stress for the root system, irrespective of the AMF treatment.

Focusing our attention on the plants cultivated in the Ascontaminated soil (La Botte), we can point out that the $\mathrm{M}+\mathrm{P}+$ plants produced a biomass $75.7 \%, 66.9 \%$ and $35.2 \%$ higher than that of the M- P-, M+ P- and M- P+ plants, respectively (Table 2; Figure 1). These results also indicated a significant $(p<0.0001)$ lower growth of the plants non-fertilized with $\mathrm{P}$; even in presence of AMF, the $\mathrm{P}$ application allowed to produce the highest biomass. A similar trend was found by Pigna et al. (2009), who noted a better growth of the P-fertilized wheat plants that were irrigated with As-contaminated water.

The fact that AMF colonization significantly $(p<$ 0.0001 ) increased biomass of escarole plants in spite of the presence of considerable amounts of As in the soil indicates the positive influence of plant-microorganisms interaction on plant growth under abiotic stress. Agely et al. (2005), colonizing Chinese brake fern (Pteris vittata L.) with AMF for phytoextraction of As from soil, demonstrated that AMF increased the plant biomass by nearby $100 \%$ compared to non-mycorrhized plants at highest As treatment. 
Table 2. Roots, leaves and total biomass of escarola plants (Cichorium endivia cv. Natacha) grown in both As-noncontaminated (Padula) and As-contaminated (La Botte) soils, in the presence or absence of P fertilization and AMF inoculation.

\begin{tabular}{|c|c|c|c|c|c|}
\hline \multirow[t]{2}{*}{ Soil } & Treatment & Roots & Leaves & Total & \multirow[t]{2}{*}{ Roots/Leaves } \\
\hline & \multicolumn{4}{|c|}{$\mathbf{g}$} & \\
\hline Padula & M- P- & $1.40 \pm 0.16 \mathrm{~d}$ & $5.60 \pm 0.60 \mathrm{~cd}$ & $7.00 \pm 0.76 \mathrm{~cd}$ & 0.25 \\
\hline Padula & $\mathbf{M}+\mathbf{P}-$ & $1.85 \pm 0.12 \mathrm{c}$ & $7.10 \pm 0.85 \mathrm{c}$ & $8.95 \pm 0.97 \mathrm{c}$ & 0.26 \\
\hline Padula & M- P+ & $2.40 \pm 0.20 \mathrm{~b}$ & $10.10 \pm 0.96 b$ & $12.50 \pm 1.16 \mathrm{~b}$ & 0.24 \\
\hline Padula & $\mathbf{M}+\mathbf{P}+$ & $3.20 \pm 0.25 \mathrm{a}$ & $13.30 \pm 1.40 \mathrm{a}$ & $16.50 \pm 1.65 \mathrm{a}$ & 0.24 \\
\hline La Botte & M- P- & $0.23 \pm 0.05 \mathrm{f}$ & $1.68 \pm 0.19 \mathrm{e}$ & $1.91 \pm 0.24 \mathrm{f}$ & 0.14 \\
\hline La Botte & $\mathbf{M}+\mathbf{P}-$ & $0.36 \pm 0.06 \mathrm{f}$ & $2.24 \pm 0.21 \mathrm{e}$ & $2.60 \pm 0.27 \mathrm{ef}$ & 0.16 \\
\hline La Botte & M- P+ & $0.61 \pm 0.08$ ef & $4.48 \pm 0.56 \mathrm{~d}$ & $5.09 \pm 0.64 \mathrm{de}$ & 0.14 \\
\hline La Botte & $\mathbf{M}+\mathbf{P}+$ & $0.92 \pm 0.10 \mathrm{e}$ & $6.94 \pm 0.55 \mathrm{c}$ & $7.86 \pm 0.65 \mathrm{c}$ & 0.13 \\
\hline \multicolumn{2}{|c|}{ AMF inoculation } & $p<0.0001$ & $p<0.0001$ & $p<0.0001$ & \\
\hline \multicolumn{2}{|c|}{$P$ fertilization } & $p<0.0001$ & $p<0.0001$ & $p<0.0001$ & \\
\hline \multicolumn{2}{|c|}{ Interaction } & $p<0.0005$ & $p<0.05$ & $p<0.01$ & \\
\hline
\end{tabular}

Data are expressed as mean values $\pm \operatorname{SD}(n=6)$ and have been analyzed by two-way analysis of variance. Mean values followed by the same letter within columns are not significantly different by Tukey's test at the $5 \%$ level. M+ and M-indicate mycorrhized and non-mycorrhized plants, respectively, while $\mathrm{P}+$ and $\mathrm{P}$ - indicate fertilized and non-fertilized plants, respectively.

\subsection{Arsenic concentration and content in plant tissues}

Table 3 shows As concentration and content in roots and leaves of escarole plants, grown in the As-contaminated soil (La Botte) and subjected to the different AMF and P treatments. Most of the As taken up by escarole plants from the As-contaminated soil was accumulated in the roots. In fact, the As content in the roots was on average 1.7 to 2.2 -fold higher than those observed in the leaves. A limited translocation of As from under- to above-ground plant tissues was also found by Carbonell-Barrachina et al. (1997) in tomato plants, who ascertained that $83.2 \%$ of the adsorbed As remained in the roots, $16.8 \%$ in the stems and only $7.3 \%$ reached the leaves. Similar results have been observed for lettuce (Cozzolino et al. 2010), rice (Rahman et al. 2007) and wheat (Pigna et al. 2009). 


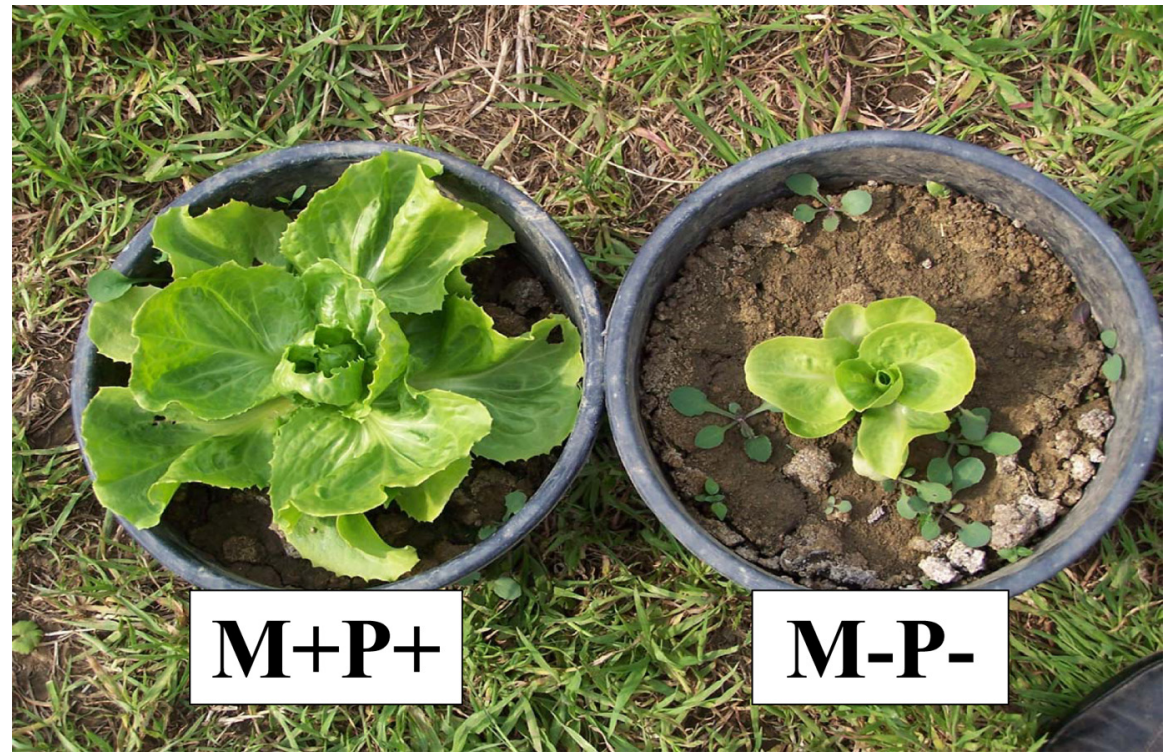

Figure 1. Comparison between the leaves biomass of a mycorrhized and fertilized escarole plant $(\mathrm{M}+\mathrm{P}+)$ and that of a non-mycorrhized and non-fertilized (M- P-) escarole plant (Cichorium endivia cv. Natacha), grown in the As -contaminated (La Botte) soil.

In addition, it is noteworthy that As concentration in roots and leaves of mycorrhized plants is lower than that observed in those non-mycorrhized (Table 3). In particular, lower As concentration was found in the leaves of $\mathrm{M}+$ versus $\mathrm{M}$ - plants (1.56 versus $1.79 \mu \mathrm{g} \mathrm{g}^{-1}$ in $\mathrm{P}+$ plants and 1.83 versus $2.10 \mu \mathrm{g} \mathrm{g}^{-1}$ in P-plants). Chen et al (2007), studying the influence of AMF on the As and P uptake by alfalfa plants (Medicago sativa), found that the colonization by these fungi reduces the As concentration both in under- and above-ground tissues of the plant.

The fertilization of the plants with $\mathrm{P}$ has also contributed to reduce the As concentration in both roots and leaves of the escarole plants (Table 3). In fact, non-resistant plants can be made more resistant to As by raising their $\mathrm{P}$ status, as the $\mathrm{P}$ is taken more effectively compared to As (Meharg and Macnair 1992; Lee et al. 2003). The reduction of sensitivity to As is given by a higher cytoplasmatic $\mathrm{P}$ concentration, which competing with As, reduces its toxic effects on plant cells (Meharg, 2004).

A much higher As content $\left(\mu \mathrm{g} \mathrm{plant}^{-1}\right)$ in plant tissues of the mycorrhized and fertilized plants $(\mathrm{M}+\mathrm{P}+)$ was found (Table 3), essentially due to the greater production of biomass. In fact, the greater biomass has determined a dilution of the harmful metalloid in plant tissues, limiting its toxic effect. A significant dilution of As in plant tissues was also found by Cozzolino et al. (2010), Liu et al. (2005b) and Chen et al. (2007), who noted a better growth of the mycorrhized plants because of their better P status. Although the combined use of AMF inoculation and $\mathrm{P}$ fertilization has allowed to minimize the As accumulation in the edible part of the escarole, it seems that more efforts in improving the cultivation technique are still necessary to produce non-toxic foods from soils highly contaminated by As, such as La Botte. 
Table 3. Arsenic concentration and content in the roots and leaves of escarole plants (Cichorium endivia cv. Natacha) grown in both As-non-contaminated (Padula) and As-contaminated (La Botte) soils, in the presence or absence of $\mathrm{P}$ fertilization and AMF inoculation.

\begin{tabular}{|c|c|c|c|c|c|}
\hline \multirow[t]{3}{*}{ Soil } & \multirow[t]{3}{*}{ Treatment } & \multicolumn{2}{|c|}{ As concentration } & \multicolumn{2}{|c|}{ As content } \\
\hline & & Roots & Leaves & Roots & Leaves \\
\hline & & \multicolumn{2}{|c|}{$\mu g^{-1}$} & \multicolumn{2}{|c|}{$\mu g$ plant $^{-1}$} \\
\hline Padula & M- P- & n.d.* & n.d.* & n.d.* & n.d.* \\
\hline Padula & $\mathbf{M}+\mathbf{P}-$ & n.d.* & n.d.* & n.d.* & n.d.* \\
\hline Padula & M- P+ & n.d.* & n.d.* & n.d.* & n.d.* \\
\hline Padula & $\mathbf{M}+\mathbf{P}+$ & n.d.* & n.d.* & n.d.* & n.d.* \\
\hline La Botte & M- P- & $26.8 \pm 2.8 \mathrm{a}$ & $2.10 \pm 0.22 \mathrm{a}$ & $6.16 \pm 0.45 c$ & $3.53 \pm 0.20 \mathrm{c}$ \\
\hline La Botte & $\mathbf{M}+\mathbf{P}-$ & $24.9 \pm 2.2 \mathrm{a}$ & $1.83 \pm 0.15 \mathrm{ab}$ & $8.96 \pm 0.60 \mathrm{c}$ & $4.10 \pm 0.34 \mathrm{c}$ \\
\hline La Botte & M- P+ & $24.2 \pm 2.5 \mathrm{a}$ & $1.79 \pm 0.13 \mathrm{ab}$ & $14.76 \pm 1.30 \mathrm{~b}$ & $8.01 \pm 0.65 b$ \\
\hline La Botte & $\mathbf{M}+\mathbf{P}+$ & $23.6 \pm 1.0 \mathrm{a}$ & $1.56 \pm 0.05 b$ & $21.71 \pm 1.88 \mathrm{a}$ & $10.82 \pm 0.80 \mathrm{a}$ \\
\hline \multicolumn{2}{|c|}{ AMF inoculation } & $p=0.3605$ & $p<0.05$ & $p<0.0005$ & $p<0.001$ \\
\hline \multicolumn{2}{|c|}{ Pfertilization } & $p=0.1687$ & $p<0.05$ & $p<0.0001$ & $p<0.0001$ \\
\hline \multicolumn{2}{|c|}{ Interaction } & $p=0.6276$ & $p=0.8234$ & $p<0.05$ & $p<0.01$ \\
\hline
\end{tabular}

Data are expressed as mean values $\pm \operatorname{SD}(n=6)$ and have been analyzed by two-way analysis of variance. Mean values followed by the same letter within columns are not significantly different by Tukey's test at the 5\% level. M+ and M-indicate mycorrhized and non-mycorrhized plants, respectively, while $\mathrm{P}+$ and $\mathrm{P}$ - indicate fertilized and non-fertilized plants, respectively. * n.d. means not detected. 
Table 4. Phosphorus concentration and content in the roots and leaves of escarole plants (Cichorium endivia cv. Natacha) grown in both As-non-contaminated (Padula) and As-contaminated (La Botte) soils, in the presence or absence of $\mathrm{P}$ fertilization and AMF inoculation.

\begin{tabular}{|c|c|c|c|c|c|}
\hline \multirow[t]{3}{*}{ Soil } & \multirow[t]{3}{*}{ Treatment } & \multicolumn{2}{|c|}{$P$ concentration } & \multicolumn{2}{|c|}{$P$ content } \\
\hline & & Roots & Leaves & Roots & Leaves \\
\hline & & \multicolumn{2}{|c|}{$\mathrm{mg} \mathrm{g}^{-1}$} & \multicolumn{2}{|c|}{ mg plant $t^{-1}$} \\
\hline Padula & M- P- & $2.38 \pm 0.19 b c$ & $2.41 \pm 0.11 \mathrm{~d}$ & $3.35 \pm 0.45 \mathrm{~cd}$ & $13.56 \pm 1.22 \mathrm{~cd}$ \\
\hline Padula & $\mathrm{M}+\mathrm{P}-$ & $2.86 \pm 0.20 \mathrm{ab}$ & $3.15 \pm 0.18 b c$ & $5.31 \pm 0.41 b c$ & $22.47 \pm 2.06 b c$ \\
\hline Padula & M- P+ & $2.75 \pm 0.21 \mathrm{abc}$ & $3.18 \pm 0.16 b c$ & $6.62 \pm 0.65 \mathrm{def}$ & $32.24 \pm 3.67 b$ \\
\hline Padula & $\mathbf{M}+\mathbf{P}+$ & $3.02 \pm 0.19 \mathrm{a}$ & $3.85 \pm 0.18 \mathrm{a}$ & $9.68 \pm 1.06 \mathrm{a}$ & $51.40 \pm 5.09 \mathrm{a}$ \\
\hline La Botte & M- P- & $2.20 \pm 0.15 \mathrm{c}$ & $2.32 \pm 0.18 \mathrm{~d}$ & $0.51 \pm 0.06 \mathrm{f}$ & $3.30 \pm 0.23 \mathrm{~d}$ \\
\hline La Botte & $\mathbf{M}+\mathbf{P}-$ & $2.58 \pm 0.24 \mathrm{abc}$ & $2.89 \pm 0.16 \mathrm{c}$ & $0.93 \pm 0.08$ ef & $6.80 \pm 0.55 \mathrm{~d}$ \\
\hline La Botte & M- P+ & $2.72 \pm 0.26 \mathrm{abc}$ & $3.06 \pm 0.20 \mathrm{c}$ & $1.66 \pm 0.12 b$ & $13.70 \pm 1.34 \mathrm{~cd}$ \\
\hline La Botte & $\mathbf{M}+\mathbf{P}+$ & $2.90 \pm 0.22 \mathrm{ab}$ & $3.60 \pm 0.15 \mathrm{ab}$ & $2.67 \pm 0.14 \mathrm{de}$ & $24.98 \pm 2.52 b$ \\
\hline \multicolumn{2}{|c|}{ AMF inoculation } & $p<0.01$ & $p<0.0001$ & $p<0.0001$ & $p<0.0001$ \\
\hline \multicolumn{2}{|c|}{ P fertilization } & $p<0.005$ & $p<0.0001$ & $p<0.0001$ & $p<0.0001$ \\
\hline \multicolumn{2}{|c|}{ Interaction } & $p=0.5381$ & $p=0.9829$ & $p<0.005$ & $p<0.01$ \\
\hline
\end{tabular}

Data are expressed as mean values $\pm \operatorname{SD}(n=6)$ and have been analyzed by two-way analysis of variance. Mean values followed by the same letter within columns are not significantly different by Tukey's test at the $5 \%$ level. M+ and M-indicate mycorrhized and non-mycorrhized plants, respectively, while $\mathrm{P}+$ and $\mathrm{P}$ - indicate fertilized and non-fertilized plants, respectively. 


\subsection{Phosphorus concentration and content in plant tissues}

Phosphorus concentration $\left(\mathrm{mg} \mathrm{g}^{-1}\right)$ and content $(\mathrm{mg}$ plant $^{-1}$ ) in the roots and leaves of escarole plants, grown in both As-non-contaminated (Padula) and As-contaminated (La Botte) soils are shown in Table 4. Regardless the soil, the combined use of AMF inoculation and $\mathrm{P}$ fertilization significantly improved $(p$ $<0.01)$ the $\mathrm{P}$ concentration in plant tissues. For example, the $\mathrm{P}$ concentration in the leaves of the mycorrhized and fertilized plants $(\mathrm{M}+\mathrm{P}+)$ grown in La Botte soil was $3.60 \mathrm{mg} \mathrm{g}^{-1}$, a value significantly $(p<0.0001)$ higher than that found in the leaves of the M- P+ plants (3.06 $\left.\mathrm{mg} \mathrm{g}^{-1}\right)$. Similarly, in the absence of $\mathrm{P}$ fertilization, the inoculation with AMF increased the $\mathrm{P}$ concentration in the leaves $\left(2.89 \mathrm{mg} \mathrm{g}^{-1}\right.$ in the $\mathrm{M}+$ plants versus $2.32 \mathrm{mg}$ $\mathrm{g}^{-1}$ in those $\mathrm{M}-$ ). A similar trend was also found in the plants grown in Padula soil (Table 4).

The $\mathrm{P}$ content in plant tissues was strongly affected by the different treatments $(p<0.0001)$, especially that observed in the leaves. Regardless $\mathrm{P}$ addition, almost a double $\mathrm{P}$ content was found in leaves of $\mathrm{M}+$ plants compared to those M- (Table 4), grown in both Padula and La Botte soils. These results confirm, once more, the important role of the AMF in $\mathrm{P}$ nutrition of the plants. With $\mathrm{P}$ supply, the mycorrhized plants were more efficient in absorbing extra available $\mathrm{P}$, compared to those non-mycorrhized. In AMF-inoculated plants mycorrhizal phosphate transporters are activated (Liu et al., 1998; Rausch et al., 2001) and loss of function of the direct uptake pathway in colonized roots by AMF can apparently be complete (Smith et al., 2003). The suppression of activity of high-affinity phosphate transporters in plant roots seems to increase As tolerance (Gonzalez-Chavez et al., 2002).

\section{Conclusions}

The findings of this study let us to assert that the combined use of AMF inoculation and $\mathrm{P}$ fertilization can significantly increase the production of biomass of escarole plants, even if grown in highly As-contaminated soils; in addition, this dual agricultural practice has also allowed to reduce the translocation of the harmful element from roots to leaves (i.e., the edible part of the escarole), minimizing, hence, the accumulation of highly toxic levels of As in food plants.

Therefore, the combined use of AMF inoculation and $\mathrm{P}$ fertilization may alleviate the As toxicity to sensitive plants as Cichorium endivia, by promoting their growth, limiting As assimilation and improving P nutrition.

\section{Acknowledgments}

This study was supported by the Italian Research Program of National Interest (PRIN 2010-2011).

\section{References}

Agely, A.A., Sylvia, D.M., Ma, L.Q. 2005. Mycorrhizae increases arsenic uptake by the hyperaccumulator Chinese brake fern (Pteris vittata L.). J. Environ. Qual. 34, 2181-2186.

Ahuja, S. 2008. The problem of arsenic contamination of groundwater. In: S. Ahuja (ed). Arsenic contamination of groundwater. Wiley, pp: 1-21.

Blakemore, L.C., Searle, P.L., Daly, B.K. 1987. New Zeeland Bureau scientific Report No. 80. Methods for Chemical Analysis of Soil. NZ Soil Bureau, Lower Hutt, New Zeland.

Carbonell-Barrachina, A.A., Burlo, F., BurgosHernandez, A., Lopez, E., Mataix, J. 1997. The influence of arsenite concentration on arsenic accumulation in tomato and bean plants. Sci. Hortic. 71, 167-176.

Chakrabarti, D., Rahman, M.M., Paul, K., Chowdhury, U.K., Sengupta, M.K., Lodh, D. 2002. Arsenic 
calamity in the Indian subcontinent. What lessons have been learned?. Talanta. 58, 3-22.

Chen, B., Xiao, X., Zhu, Y.G., Smith, F.A., Xie, Z.M., Smith, S.E. 2007. The arbuscular mycorrhizal fungus Glomus mosseae gives contradictory effects on phosphorus and arsenic acquisition by Medicago sativa Linn. Sci. Total Environ. 379, 226-234.

Cozzolino, V., Pigna, M., Di Meo, V., Caporale, A.G., Violante, A. 2010. Effects of arbuscular mycorrhizal inoculation and phosphorus supply on the growth of Lactuca sativa L. and arsenic and phosphorus availability in an arsenic polluted soil under nonsterile conditions. Appl. Soil Ecol. 45, 262-268.

Frankenberger Jr., W.T. 2002. Environmental Chemistry of Arsenic. Marcel Dekker, New York, $391 \mathrm{pp}$.

Gonzalez-Chavez, C., Harris, P.J., Dodd, J., Meharg, A.A. 2002. Arbuscular mycorrhizal fungi enhanced arsenate resistance on Holcus lanatus. New Phytol. 155, 163-171.

Lee, D.A., Chen, A., Schroeder, J.I. 2003. Ars1, an Arabidopsis mutant exhibiting increased tolerance to arsenate and increased phosphate uptake. Plant J. 35, 637-646.

Liu, H., Trieu, A.T., Blaylock, L.A., Harrison, M.J. 1998. Cloning and characterization of two phosphate transporters from Medicago truncatula roots: regulation in response to phosphate and response to colonization by arbuscular mycorrhizal (AM) fungi. Mol. Plant Microbe Interact. 11, 14-22.

Liu, X., Zhang, S., Shan, X., Zhu, Y.G. 2005a Toxicity of arsenate and arsenite on germination seedling growth and amylolytic activity of wheat. Chemosphere. 61, 293-301.

Liu, Y., Zhu, Y.J., Chen, P., Christie, P., Li, X.L. 2005b. Yield and arsenate uptake of arbuscolar mycorrhyzal tomato colonized by Glomus mosseae BEG167 in as spiked soil under glasshouse conditions. Environ. Int. 31, 867-873.

Mandal, B.K., Suzuky, K.T. 2002. Arsenic round the world: a review. Talanta. 58, 201-235.

Meharg, A.A., Macnair, M.R. 1992. Suppression of the high affinity phosphate uptake system a mechanism of arsenate tolerance in Holcus lanatus L. J. Exp. Bot. 43, 519-524.

Meharg, A.A. 1994. Integrated tolerance mechanisms constitutive and adaptive plant responses to elevated metal concentrations in the environment. Plant, Cell \& Environ. 17, 989-993.

Meharg, A.A., Hartley-Whitaker, J. 2002. Arsenic uptake and metabolism in arsenic resistant and non resistant plant species. The New Phytol. 154, $29-43$.

Nelson, D.W., Sommers, L.E. 1982. Total carbon, organic carbon and organic matter. In: A.L. Page, R.H. Miller, D.R. Keeney (eds). Methods of Soil Analysis, Part 2. American Society of Agronomy, Madison, WI, pp: 539-579.

Pigna, M., Cozzolino, V., Violante, A., Meharg A.A. 2009. Influence of phosphate on the arsenic uptake by wheat (Triticum durum L.) irrigated with arsenic solutions at three different concentrations. Water Air \& Soil Poll. 197, 371-380.

Rahman, M.A., Hasegawa, H., Rahman, M.M., Rahman, M.A., Miah, M.A.M. 2007. Accumulation of arsenic in tissues of rice plant (Oryza sativa L.). Chemosphere. 69, 942-94.

Rausch, C., Darram, P., Brunner, S., Jansa, J., Laloi, M., Leggewie, G., Amrhein, N., Bucher, M. 2001. A phosphate transporter expressed in arbuscule-containing cells in potato. Nature. 414, 462-470. 
Shuman, L.M. 1982. Separation soil iron and manganese oxide fractions for microelement analysis. Soil Sci. Soc. Am. J. 46, 1099-1102.

Smith, E., Naidu, R., Alston, A.M. 1998. Arsenic in the soil environment: A review. Adv. Agron. 64, 149-195.

Smith, S.E., Christophersen, H.M., Pope, S., Smith, F.A. 2010. Arsenic uptake and toxicity in plants: integrating mycorrhizal influences, Plant Soil. $327,1-21$.

Smith, S.E., Read, D.J. 2008. Mycorrhizal Symbiosis, 3th Edition, Elsevier.

Smith, S.E., Smith, A.F., Jakobsen, I. 2003. Mycorrhizal fungi can dominate phosphate supply to plants irrespective of growth responses. Plant Physiol. 133, 16-20.

Stone, R. 2008. Food safety - arsenic and paddy rice: A neglected cancer risk?. Sci. 321, 184-185.
Ultra, V., Tanaka, S., Sakurai, K., Iwasaki, K. 2007. Effects of arbuscular mycorrhiza and phosphorus application on arsenic toxicity in sunflower (Helianthus annus L.) and on the transformation of arsenic in the rhizosphere. Plant Soil. 290, 29-41.

Violante, A., Pigna, M., Cozzolino, V., Huang, P.M. 2012. Impact of soil physical, chemical and biological interactions on the transformation of metals and metalloids. In: P.M. Huang, Y. Li, M.E. Summer (eds). Handbook of soil science resource of management and environmental impacts, Second Edition. CRC Press, Boca Raton, pp. 1-30.

Wu, F. 2008. Colonization and species diversity of arbuscular mycorrhizal fungi and their effects on metal tolerance and metal accumulation in two metal hyperaccumulators, Pteris vittata and Sedum alfredii. Doctoral thesis, Hong Kong Baptist University.

Xu, Y.Y., McGrath, S.P., Meharg, A.A., Zhao, F.G. 2008. Growing rice aerobically markedly decreases arsenic accumulation. Environ. Sci. Technol. 42, 5574-5579. 